\title{
The DP hypothesis and the syntax of identification
}

\section{Anne Zribi-Hertz}

\section{OpenEdition}

\section{Journals}

Édition électronique

URL : http://journals.openedition.org/rlv/428

DOI : $10.4000 /$ rlv.428

ISSN : 1958-9239

\section{Éditeur}

Presses universitaires de Vincennes

\section{Édition imprimée}

Date de publication : 1 juin 2002

Pagination : 127-142

ISBN : 2-84292-119-4

ISSN : 0986-6124

\section{Référence électronique}

Anne Zribi-Hertz, "The DP hypothesis and the syntax of identification », Recherches linguistiques de Vincennes [En ligne], 31 | 2002, mis en ligne le 06 juin 2005, consulté le 20 avril 2019. URL : http:// journals.openedition.org/rlv/428; DOI : 10.4000/rlv.428 
Recherches linguistiques de Vincennes 31 - 2002 - p. 127-142

\author{
Anne ZRIBI-HERTZ \\ UMR 7023, CNRS/Université Paris-8
}

THE DP HYPOTHESIS AND THE SYNTAX OF IDENTIFICATION

\begin{abstract}
This paper addresses the problem of locating 'definiteness', i. e. the feature(s) responsible for referent-identification, within noun phrase structure. Considering comparative data from French and Haitian, it questions the current assumption that definiteness is a binary feature ( \pm definite) generated (or checked) in a functional phrase 'DP' projected in topmost position. It is argued that 'definiteness' effects may result from at least two types of features - the categorial feature [n], and locative features - which may occupy different positions within the noun phrase and may also combine to form a functional shell. It is further argued on the basis of Haitian evidence that Number may be projected above identification features in syntactic structure.
\end{abstract}

KEY-WORDS

Definiteness, identification, noun phrase structure, DP hypothesis, French, Haitian, creole genesis. 


\section{Introduction}

'Definiteness' is commonly characterized in semantic terms involving such notions as presupposition of existence (Frege 1892, Russell 1905), discourse familiarity (Christophersen 1939, Jespersen 1943, Kempson 1975, Heim 1988), shared knowledge (Hawkins 1978), inclusiveness (Hawkins 1978, Milsark 1977, Holmback 1984), uniqueness (Corblin 1987), accessibility (Kempson 1988), or identifiability (Kempson 1975, Crystal 1991, Lyons 2000). It is widely assumed that the definite or nondefinite construal of a noun phrase is crucially sensitive to factors which are not inherent to the noun phrase itself, such as tense, aspect, or structural position. Nevertheless, various recent linguistic works including Lyons (2000) and Longobardi (1994, 2000) have proposed to locate Definiteness within the structure of noun phrases, analysing it as a binary feature ( \pm definite) subsuming the semantic effects loosely enumerated above. A common idea is that the $[ \pm$ definite] feature is generated in the syntactic projection DP, which is crucially assumed to be located above all other functional heads within the noun phrase, with the possible exception of Case $(\mathrm{K})$; in particular, DP must be located above NumP, the Number Phrase. Opinions vary as to whether or not the DP projection should be assumed to be present in languages which have no overt definiteness marker, but this issue may be left open here since we shall be focusing on French and Haitian, two languages officially acknowledged as having a definite determiner. Thus the two examples in (1) would be described in all textbooks as including a [+definite] object DP:

$\begin{array}{llll}\text { (1) a. Tu as } & \text { sorti } & \text { la poubelle? } & \text { (French) } \\ 2 \text { sg have taken out DF/Fsg dustbin(Fsg) } & \\ \text { b. Ou mete poubèl-la deyò? } & \text { (Haitian) } \\ 2 \text { sg put dustbin DF out } & \\ \text { 'Have you taken out the dustbin?' }\end{array}$

Under the DP hypothesis, the internal structure of the object la poubelle in (1a) may be represented as in (2a) or (2b), where the definite article is generated either in the $\mathrm{D}^{\circ}$ head or in spec, DP (leaving out functional projections other than DP):

(2) a.

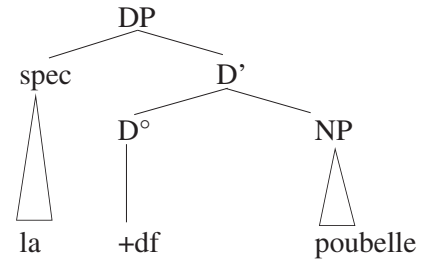

(Lyons 2000)
(2) b.

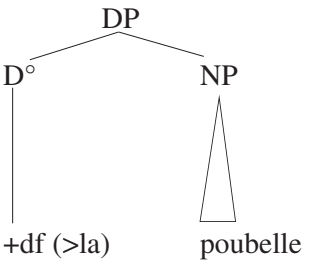

(wide-spread assumption)

Two competing analyses have also been put forward regarding the internal structure of the object poubèl-la in Haitian (1b): 
(3) a

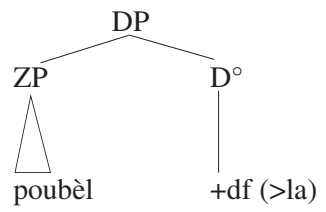

(3) b.

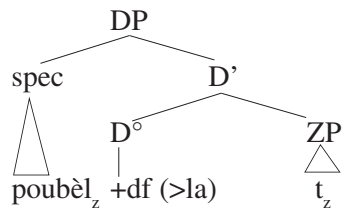

Under (3a) (Gadélii 1997, Lefebvre 1998), the Haitian DP is head-final. Under (3b) (Déprez 2000, Lyons 2000), the head-final linear order results from ZPmovement to spec, DP. What is common to all these analyses of (1a) and (1b) is that a semantically 'definite' noun phrase is assumed to contain a [+definite] feature generated throughout languages in the same topmost projection: DP.

Limiting myself to the data of French and Haitian, and to the internal structure of noun phrases (as opposed to noun-phrase-external factors), I would like to question the above assumptions regarding the syntax of definiteness. I shall argue that referent identification ('definiteness') cannot be associated with a single structural projection, nor with a single feature, but should rather be described as a class of interpretive effects triggered by several types of combinable features pertaining to various structural positions.

\section{Identification features in the French noun phrase}

Let us consider (some of) those features which have an identiying force within the French noun phrase, $i$. $e$. whose occurrence contributes to point to a certain referent. My first descriptive proposals will be three-fold:

(i) The feature spelt out as [1] (the so-called definite article) has a purely categorial content

(ii) The feature spelt out as [c] (the demonstrative determiner) is generated in the same structural position as [1], but has a locative content

(iii) Referent-identification may crucially involve a combination of two features generated in two distinct functional heads.

\subsection{Definite [1]}

The three forms of the French definite article, le, la, les, are made up of two morphological constituents, respectively spelt out by the initial consonant [1] and by the following vowel:

$$
\{-\mathrm{F},-\mathrm{pl}\} \boldsymbol{l}(\boldsymbol{e})[1] \quad\{+\mathrm{F},-\mathrm{pl}\} \boldsymbol{l} \text { - } \boldsymbol{a}[\mathrm{la}] \quad\{+\mathrm{pl}\} \text { l-es }[1 \varepsilon]
$$

Under current syntactic assumptions, the phi-features spelt out by the vowel originate in heads located below the DP projection, respectively $\mathrm{n}^{\circ}$ or $\mathrm{N}^{\circ}$ (for Gender), and $\mathrm{Num}^{\circ}$ (for Number). It follows that the initial [1] must spell out the remaining feature - the identifying feature labeled [+definite], the one responsible for the semantic contrast between, e. g., (4a) and (4b): 
(4) a. Je veux trois poubelles.

'I want three dustbins.' (unidentified, [-definite] dustbins)

b. Je veux les trois poubelles.

'I want the three dustbins.' (identified, [+definite] dustbins)

It is however interesting to look more closely at the semantic import of [1] in paradigm (4), which for convenience's sake I shall call definite [1]. We know that definite [1] is historically derived from Latin ille and is common to definite articles and definite (third-person) pronouns. That definite [1] has lost the obviation feature which ille carried in Latin is shown by the Latin example (5) and its Modern-French literal translation (6) ${ }^{1}$ :

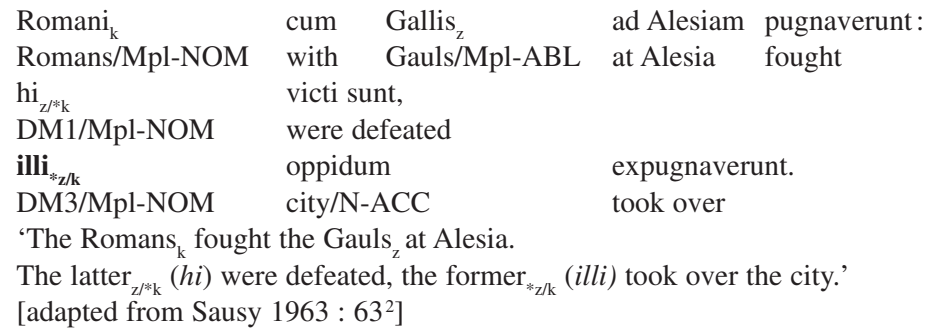

(6) Les Romains ${ }_{\mathrm{k}}$ combattirent à Alésia contre les Gaulois : $_{\mathrm{z}}$

the Romans fought at Alesia against the Gauls

ceux-ci ${ }_{z / * k}$ furent vaincus, ils $\mathbf{z}_{\mathbf{z} \mathbf{k}}$ prirent la ville d'assaut.

DM/Mpl-LOC (+ prox) were defeated, they took the city over

'The Romans $s_{k}$ fought the Gauls ${ }_{\mathrm{z}}$ at Alesia: the latter ${ }_{\mathrm{z} / \mathrm{k}}$ were defeated, they $\mathrm{z}_{\mathrm{z} / \mathrm{k}}$ took over the city.'

Latin illi, in (5), identifies the most distant available referent, whereas French ils in (6) is unspecified for obviation. The loss of the obviation feature extends to determiner [1], as shown by (7), where the identified fly may be positioned at any distance from the utterance source, including on the speaker's own body:

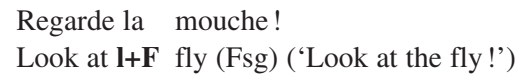

We might consider the assumption that the identifying force of definite [1], exemplified by (5b), should boil down to a deictic locative feature unspecified for obviation. Such a feature is indeed attested in French, as exemplified by the functional locative $l \grave{a}^{3}$ :

$$
\begin{array}{ll}
\text { Je mets toujours mes lunettes } & \text { là. } \\
\text { I put always my reading glasses } & \text { LOC. ('I always put my glasses \{here/there }\} . ')
\end{array}
$$

In (8), the deictic value of là is revealed by the available ostensive reading, which involves its association with some identified portion of space. French là is nevertheless unspecified for obviation, unlike its two possible English translations here and there: in (8), là may identify either a nondistal location (as opposed to 
là-bas, +distal), or a nonproximal location (as opposed to ici, +proximal). This example therefore shows that locative deixis is independent from obviation, a result compatible with the assumption that the definite [1] of Modern French might have held on to the deictic-locative feature of Latin ille, while shedding its obviative feature. Such cannot be the case, however, if we consider some familiar properties involving binding. The following examples show that là cannot be construed as a bound variable, contrasting in this respect with $y$ (the locative pronoun) and other pronominals (including [1]) :

(9) a. Ce bâtiment ${ }_{z}$ mériterait qu'on $\quad$ *habite là $/ / \mathbf{y}_{\mathbf{z}}$ habite .

$\mathrm{DM} / \mathrm{Msg}$ building (Msg) would deserve that people \{live LOC//LOC live $\}$

'This/that building would deserve that people should $\{$ live here/there//live in it $\} . '$

c. Ce bâtiment $t_{z}$ mériterait qu'on $\mathbf{l e}_{\mathrm{z}}$ repeigne.

'This/that building $\mathrm{z}_{\mathrm{z}}$ would deserve that people should repaint it $\mathrm{z}_{\mathrm{z}}$.

The ungrammaticality of là in (9a) may be attributed to its deictic content, which makes it unavailable for binding. Contrastively, the bound locative clitic y in (9b) may be assumed to lack deictic content. This result extends to [1] in (9c). Empirical evidence thus leads me to conclude that the definite [1] of Modern French lacks a deictic feature and is specified neither for obviation nor for spatialization $^{4}$. We may assume that definite [1] spells out a purely categorial (nominal) feature [n] (an assumption compatible with the double status of [1] as '3rd-person pronoun' and 'determiner') and that the semantic contrast between, e. $g$., (4a) and (4b) thus boils down to the fact that the object noun phrase of (4b) contains an extra nominal constituent ${ }^{5}$ which is lacking in (4a). I shall now argue that since identification markers vary in both feature content and distribution, 'definiteness' cannot be regarded as a binary feature.

\subsection{Split identification and the D-C correlation}

It is common knowledge that in a definite noun phrase including a restrictive relative clause, $e . g$. (10a), the restrictive import of the relative clause plays a crucial role in referent-identification. Kayne (1994) extends this idea to noun phrases including a genitive modifier, such as (10b), and formalizes it within the X-bar framework along the lines sketched in $(11)^{6}$ :

(10) a. la valise rouge que Marie a achetée
the suitcase red that Marie has bought ('the red suitcase that M. bought')
b. la valise
the suitcase rouge de Marie


(11)

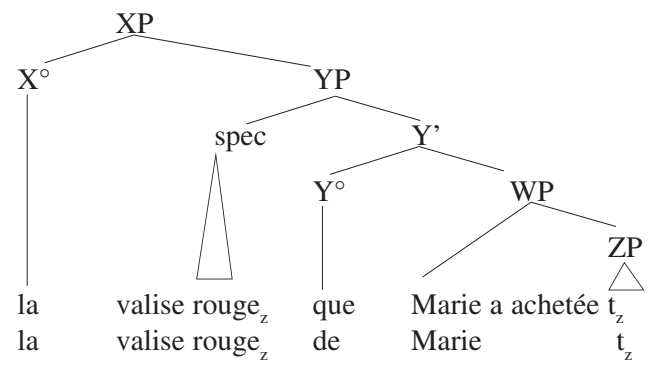

The central assumption which underlies (11) is that the lexical component valise rouge does not form a constituent with the definite determiner, but originates within the predicate of the WP phrase (a verbal or nominal predication). Instead, the discontinuous strings l-... que... and l-... de... are analysed as forming what I shall call an XP shell, involving two functional heads $\left(\mathrm{X}^{\circ}\right.$ and $\left.\mathrm{Y}^{\circ}\right)$, within which $\mathrm{ZP}$ movement takes place. As regards relativized noun phrases, this assumption is consistent with historical evidence showing the correlative character of $\mathbf{l}-. .$. que... ( $c f$. Meillet \& Vendryès 1979, Muller 1996, Sandfeld 1965). The analysis sketched in (11) is crucially supported by the contrast between (12) and (13):

(12) a. Il a $\{$ une/*la $\}$ manière bizarre de me regarder.

'He has $\{a / *$ the $\}$ weird way of looking at me.'

b. Il a (*la) peur d'aller plus loin.

'He has (*the) fear of going further.' ('He is afraid of going further.')

(13) a. la manière bizarre qu'il a de me regarder

'the weird way that he has of looking at me'

b. la peur qu'il a d'aller plus loin

'the fear that he has of going further'

The examples in (12) show that nouns such as manière 'manner' or peur 'fear', when governed by the verb avoir 'have', do not license the definite determiner. It follows that the definite article cannot form a constituent with the following noun in (13), and must be licensed by the relative clause itself. Under the XP-shell assumption in (11), the functional features which identify the referent of restricted noun phrases such as those in (10) cannot be limited to whatever feature is located in the $\mathrm{X}^{\circ}$ head, but are distributed over the two heads $\mathrm{X}^{\circ}$ and $\mathrm{Y}^{\circ}$ which form the backbone of the XP shell.

\subsection{Locative identification features}

Consider the type of demonstrative noun phrase exemplified in (14):

J' aime bien ce petit livre -ci,
1sg like pas


In such cases the demonstrative determiner is spelt out by a discontinuous string including the prenominal element [c] supporting nominal phi-features, and a phrase-final uninflected locative specified in one case for obviation ( $c i$ is +proximal, while là is unspecified, $c f$. section 2.1). The XP-shell pattern adopted above in (11) provides us with a straightforward syntactic representation for the discontinuous demonstrative ${ }^{7}$ :

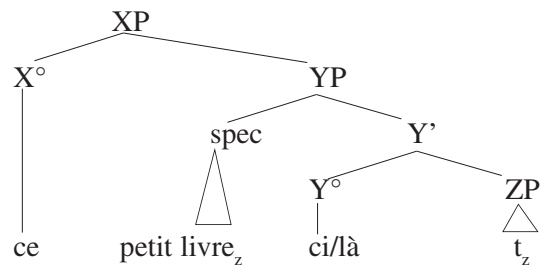

This analysis is consistent with at least three facts :

First, demonstrative [c] and definite [1] do not combine, and this restriction cannot derive from some independent incompatibility between 'definite' and 'demonstrative' markers, since they combine in many languages, among which Haitian :

French

(16) a. Le petit livre n'est pas bon. ('The little book is not good.')

b. Ce petit livre n'est pas bon. ('This/that little book is not good.')

c. $*\{$ Le ce/ce le $\}$ petit livre n'est pas bon.

$\underline{\text { Haitian }}$

(17) a. Liv la pa bon. book LA NEG good ('The/this (preidentified) book is not good.')

b. Liv sa (l) a pa bon.

book DM LA NEG good. ('This/that book (ostensive) is not good.')

Under the analysis sketched in (11) and (15), the restriction revealed by (16c) is due to the fact that definite [1] and demonstrative [c], in French, compete for the same $\left(\mathrm{X}^{\circ}\right)$ head.

Second, Diagram (15) captures the c-... ci/là correlation in a natural way, aligning it on the restrictive-relative structure represented in (11). This parallelism is further supported by the fact that [c], like [1], may select as its complement a restrictive clause headed by $q u-$, as in (18b), and that ci/là is in complementary distribution with $q u-$, as witnessed by (18c) - a fact also noted by Bernstein (1997):

(18) a. $\{*$ Le/ce $\}$ petit livre -là , il n' est pas intéressant. little book LOC it NEG is NEG interesting

'This/that little book, it is not interesting.'

b. $\{$ Le/ce $\}$ petit livre que Marie a acheté, il n' est pas intéressant. little book that Marie bought it NEG is NEG interesting

' $\{$ The/this $\}$ little book that Marie bought, it is not interesting.' 8

c. $*\{$ Le/ce $\}$ petit livre là que Marie a acheté, il n'est pas intéressant. 
These data bring out a selectional relation between the feature contents of the $\mathrm{X}^{\circ}$ and $\mathrm{Y}^{\circ}$ heads within diagrams (11) and (15): $q u$ - in $\mathrm{Y}^{\circ}$ may license either [c] or [1] in $\mathrm{X}^{\circ}, \mathrm{LOC}$ in $\mathrm{Y}^{\circ}$ must be licensed by [c] in $\mathrm{X}^{\circ}$, and the structure provides space for only one element in $\mathrm{Y}^{\circ}$. In (17b), the [1] and [c] options contrast semantically in that demonstrative [c] triggers a discourse-linked construal of the referent.

Third, the opposition between [1] and [c] is neutralized in relativized noun phrases lacking a lexical head. In such cases the relativized ZP is reduced to its Gender and Number features spelt out by, e.g., lui (in the Msg), and [c] is the only legitimate determiner:

$$
\begin{array}{lllll}
\text { J' } & \text { aime bien les } & \text { livres, } & \text { mais } \\
1 \text { sg } & \text { like well } & 1+\mathrm{pl} & \text { books }(\mathrm{Mpl}) & \text { but } \\
\{* l e / c e\} & -l u i & \text { que } & \text { Marie a acheté n' est pas intéressant. } \\
& \text { Msg } & \text { that } & \text { Marie bought NEG is NEG interesting } \\
& \text { 'I do like books, but the one that Marie bought is not interesting.' }
\end{array}
$$

The restriction observed in (19) may be attributed to the fact that the lack of a lexical N-head necessarily correlates with a discourse-linked (anaphoric) construal of the referent, a property shown above ( $c f$. (18b)) to call for the [c] option.

Demonstrative [c] may also occur without an overt locative correlate in $\mathrm{Y}^{\circ}$, as in $(20)$ :

$$
\text { J'aime bien ce livre. ('I like this/that book.') }
$$

I assume the informative content of [c] to be essentially the same as that of là, described above: it has a locative force which is lacking in definite [1], a contrast which correlates with the many semantic effects studied by Kleiber $(1981,1983$, 1984, 1986). Under this assumption, such strings as ce petit livre-là (cf. (14)) in effect contain two instances of the same [locative] feature. This of course does not mean that locative-doubling is semantically vacuous — the following example shows that it is not:

(21) [context: a fly is insistently buzzing around the speaker's nose]
a. La mouche m'embête.
('The fly is bothering me.')
b. Cette mouche m'embête.
('This fly is bothering me.')
c. *Cette mouche-là m'embête.
('THIS/THAT (one) fly is bothering me.')

In (21a), definite [1] involves no locative feature - the unspatialized fly is identified by pragmatic inference ('whatever fly is relevant to utterance'); (21b) contains one locative feature in $\mathrm{X}^{\circ}$, spelt out [c], triggering weak (presupposed) spatialization: 'locate fly in utterance space'; in (21c), a second locative feature in $\mathrm{Y}^{\circ}$ triggers strong (asserted) spatialization, which conflicts with the pragmatic context (there being only one fly, ostension is irrelevant).

The French discontinuous demonstrative confirms the conclusion that referent-identifying features are not restricted to the topmost functional head $\mathrm{D}^{\circ}$ $\left(=\mathrm{X}^{\circ}\right)$, but may occur in at least one other functional head, labeled $\mathrm{Y}^{\circ}$ above. 


\section{Identification features in the Haitian noun phrase}

Let us now consider briefly the internal make-up of Haitian noun phrases 9 . The so-called definite determiner, spelt out $l a$, occurs at the right periphery in the nonplural and optionally combines with demonstrative $s a$ to its left:

(22) a. Mari achte ti liv la.

Mary bought little book LA ('Mary bought \{the/this $\}$ little book.') (preidentified)

b. Mari achte ti liv sa (1)a.

'Mary bought this/that little book.' (ostensive).

In a pluralized definite noun phrase, however, the plural marker, yo, surfaces to the right of $l a$ :

(23) Mari achte ti liv (sa) la yo.

'Mary bought \{the/these/those $\}$ little books.'

In most Haitian dialects, definite la fails to appear when the plural marker yo is present. In the Northern dialect, however, it overtly occurs in the linear position indicated in (23). Within the X-bar framework, this might lead us to assume that Number dominates Definiteness in the Haitian noun phrase, as considered in (24):

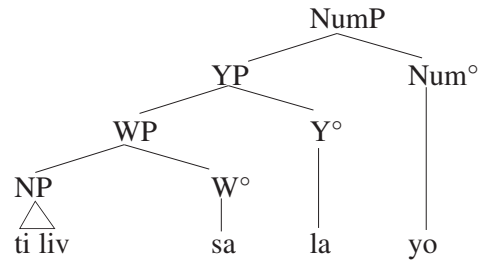

This analysis would however run against the current assumption that the Determiner projection pertains to the functional periphery and should generally dominate NumP, an inflectional projection. To conciliate the Haitian facts with the DP hypothesis, two available lines of analysis may be considered: Lefebvre's (1998) assumption that Number moves up to $\mathrm{D}^{\circ}$, represented in (25a); and the theory developed by Aboh (this volume) with respect to Gbe, involving successive-cyclic movement of WP, first to spec, NumP, then to spec, DP ( $c f$. (25b)) :

(25) a.

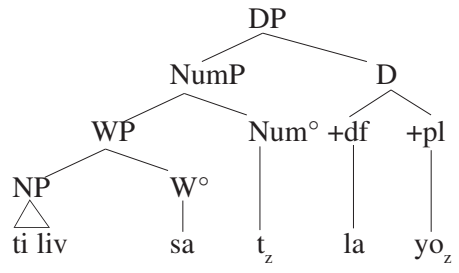

(Lefebvre 1998)

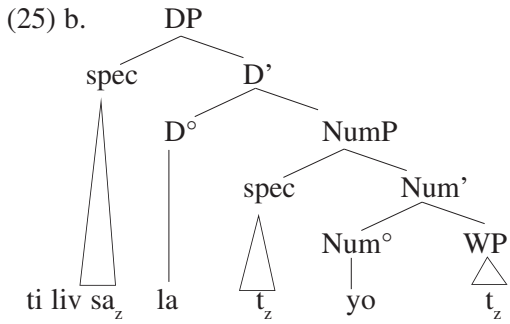

(adapted from Aboh, this volume) 
In stipulating that the plural marker yo undergoes movement, Lefebvre's analysis (25a) implies that the linear order yo la is more basic or more canonical than the attested sequence la yo, an assumption consistent with the DP hypothesis but devoid of explanatory force until supported by independent evidence. However, yo-movement to $\mathrm{D}$ in (25a) has no empirical motivation in a language lacking inflectional morphology ${ }^{10}$. This problem does not arise under (24) and (25b), which both treat the sequence la yo as basic. Analysis (24) would be consistent with a superstrate-continuous approach to Haitian, since the string la yo looks like a natural continuation of the string là, eux in French (26), where là, located in the $\mathrm{Y}^{\circ}$ head $[c f .(15)]$ must precede $\operatorname{eux}$ (a right-dislocated pronoun, adjoined to the entire noun phrase):

Ces petits livres-là, eux , ils sont vraiment intéressants. DMpl little books LOC $3 \mathrm{Mpl} 3 \mathrm{Mpl} / \mathrm{NOM}$ are really interesting 'These/those little books, THEY/THEM, they are really interesting.'

Note, however, that French (27) is also acceptable alongside (26):

Ces petits livres, \{là, eux,/eux, là, $\}$ ils sont vraiment intéressants.

'These/those little books, \{there, THE $\{\mathrm{Y} / \mathrm{M}\}$

$\{\mathrm{THE}\{\mathrm{Y} / \mathrm{M}\}$, there, $\}$ they are really interesting.'

In (27), contrasting with (26), the strong pronoun (eux) and the locative (là) are both freely adjoined to the noun phrase and may freely exchange positions. The fact that the sequence la yo should have arisen in Haitian, seemingly violating the DP hypothesis, and in spite of the acceptability of eux, là in French (27), rather suggests that the configuration underlying (26) played a crucial role in the genesis of Haitian noun phrase structure. Should this assumption be correct, we should conclude that the linear order la yo in Haitian is basic, rather than derived by movement as considered in (25a).

Analysis (25b), developed by Aboh for Gbe, could on the other hand be consistent with a substrate-driven conception of creole-genesis (taking Gbe as a substratic candidate for Haitian). An empirical problem, however, is that analysis (25b), applied to Haitian, makes it difficult to account for the crucial solidarity between demonstrative $s a$ and 'definite' la, illustrated by the following paradigm:

(28) a. Mari achte ti liv la.

Mary bought little book LA 'Mary bought the little book.' (preidentified)

b. Mari achte ti liv sa (1)a.

'Mary bought this/that little book (ostensive).'

c. *Mari achte ti liv sa.

The ungrammaticality of (28c) shows that the occurrence of $s a$ requires that of $l a^{11}$. However, under (25b), it is not clear how the $l a / s a$ dependency might be explicited, since the two elements belong to two distinct subdomains of the noun phrase. Note that in order to account for (28a), WP should be predicted to move up to spec, DP even when $s a$ does not occur, which makes it impossible to assume 
that WP movement is triggered by the 'attraction' of sa by la. This problem, however, does not arise under analysis (24), where the sa/la dependency may be simply described as a local restriction (a sa phrase must be selected by la). Empirical evidence thus seems to me to favour analysis (24) over both (25a) and (25b), although it conflicts with the view that the identification phrase labeled DP should be universally projected above Number.

It might be argued that the content of Haitian la is not, or no longer, that of French là, in other words, that French là has been 'relexified' ( $c f$. Lefebvre 1998) into a 'definite determiner' whose informative import is similar to that of French [1] or of Gbe lo ( $c f$. Aboh, this volume). Under this assumption, one might hold on to the syntactic representation in (25a), regarding it as a purely synchronic assumption involving a crucial discontinuity between the grammars of French and Haitian. This theory however runs against empirical evidence, since we have seen that the sequence la yo in Haitian mirrors French là eux in (26), and since the la/sa dependency in Haitian echoes the ce/là dependency in French. Empirical evidence clearly shows that Haitian la contains a locative feature, since it is barred from contexts which preclude spatialization of the referent, contrasting in this respect with French definite [1], which for instance allows a generic reading:

\section{(29) $\underline{\text { French }}$}

a. Le riz est bon pour les enfants.

$\mathbf{l}$ rice is good for $\mathbf{l}+\mathbf{p l}$ children ('Rice is good for children.')

Haitian

b. diri bon pou timoun.

rice good for child(ren)

c. diri la bon pou timoun.

rice LA good for child (ren) ('This rice is good for the child species.')

d. diri la bon pou timoun la.

rice LA good for child LA ('This rice is good for the/this child.')

Due to the locative feature of Haitian $l a$, French-Haitian pairs such as (1a/b) above are not actually semantically equivalent, as faultily suggested by my previous translations: in French (1a) the dustbin (la poubelle) is identified by pragmatic inference, without spatialization ('find whatever poubelle item is relevant to the utterance') ; whereas in Haitian (1b) the dustbin (poubèl la) is marked as spatialized ('find poubèl item located in relevant utterance space'). In other words, French (1a) literally means 'Did you take out a certain dustbin that we both know had to be taken out?', whereas Haitian (1b) should rather be understood as 'Did you take out a certain dustbin that I presuppose that you have correctly located?'. In the context considered, these two different construals of the referent are however likely to point to the same object in the physical world.

Last but not least, it is worth mentioning that Haitian $l a$ is morphologically and historically unrelated to third-person pronouns, which are specified for number ( $\mathrm{sg} l i, \mathrm{pl}$ yo) and (like French personal pronouns) bear no locative feature. 
Considering the locative content of Haitian la, its non-relation to 3rdperson pronouns, and its historical relation to French là, which also occurs in a functional head as a referent-identifier, I find little enlightenment in the assumption hat the $\mathrm{Y}^{\circ}$ head in the French configuration (15) has become, in Haitian, the $\mathrm{D}^{\circ}$ head in one of the diagrams in (3) or (25) - unless we accept to take ' $\mathrm{D}$ ' as a variable node label irrespective of both feature content and hierarchical position. Empirical evidence is consistent with an analysis of Haitian $l a$ as the straightforward continuation of French là in diagram (15), whose repositioning in Haitian (24) results from the loss of the inflectional $\mathrm{X}^{\circ}$ head, and from the reanalysis of a dislocated plural pronoun as a topmost Number head ${ }^{12}$.

\section{Conclusion}

The data considered in this article lead me to conclude that referent 'identifiability' does not stand as a compact semantic property which might be expressed as a binary feature (e.g. \pm definite). At least two classes of features within the noun phrase - the categorial [n] feature, and locative and obviation features - contribute to referent identification, which may also arise from a combination of two features generated in two adjacent heads within a functional shell. This assumption makes it difficult to maintain that referent-identification is located in a single ' $\mathrm{D}$ ' head. The Haitian data further suggest that number may be specified above identification in syntactic structure. It thus seems more reasonable to regard referent identification, commonly known as definiteness, not as a single feature generated in the topmost head of the noun phrase, but as a complex semantic effect resulting from various features distributed across a set of structural positions.

\section{NOTES}

1. Abbreviations used in the glosses: $\mathrm{ABL}=$ ablative case; $\mathrm{ACC}=$ accusative case ; $\mathrm{DM}=$ demonstrative; DM1 = first-degree (-distal) demonstrative (linked to the first person); DM3 = third degree (+distal) demonstrative (linked to the third person); $\mathrm{F}=$ feminine gender $; \mathrm{LOC}=$ locative $; \mathrm{M}=$ masculine gender $; \mathrm{N}=$ neuter ; $\mathrm{NOM}=$ nominative case $; \mathrm{pl}=$ plural $; \mathrm{sg}=$ singular $; \mathrm{SUBJ}=$ subjunctive. Capitalized items in English translations indicate focal stress.

2. The translation proposed for this example is itself an English adaptation of Sausy's French translation: '[...] ceux-ci furent vaincus, ceux-là prirent la ville d'assaut'. Anne Daladier (p.c.) points out that Latin illi in (5) might have been more accurately translated by an emphatic pronoun, something like: '[...] as for THEM, they took over the city'. The only point I am trying to make here is that Latin illi identifies the remote referent (the Romans) in (5), whereas French ils does not do so in (6).

3. On French locative adverbials, see Kleiber (1993).

4. I borrow the words spatialize/spatialization from the (French) Sign Language terminology, where they denote an identification strategy consisting in associating each referent with a given portion of space; signed spatialization may be regarded as the gestural spell-out of a [locative] feature. 
5. The idea that French-type definite articles are 'pronouns' is developed by Lujan (2000). It is not synonymous with the widespread reverse assumption that 'pronouns are determiners' ( $c f$. Postal 1969, Emonds 1985).

6. Regarding relativized noun phrases, Kayne (1994) rephrases an older idea expressed, e. g., by Vendler (1967), Schachter (1973) and Vergnaud (1974,1985).

7. A different analysis of French complex demonstratives is proposed by Bernstein (1997), who assumes that proclitic ce/cette/ces raises to $\mathrm{D}^{\circ}$ from the specifier of a distinct functional phrase, whose head hosts the -ci/là enclitics. However, as acknowledged by Bernstein herself (fn.6), French proclitic demonstratives do not exhibit the adjectival behaviour which ought to support the Spec assumption (cf. Giusti 1993).

8. Whatever the item ([1] or [c]) selected in the $X^{\circ}$ head, the relative clause of (18b) must of course be construed as restrictive, not as appositive. Appositive relative clauses are not considered in this article.

9. On noun-phrase structure in Haitian, see De Graff (1994), Déprez (2000), Gadélii (1997), Joseph (1988), Lefebvre (1998), Pompilus (1976), Sylvain (1936), Zribi-Hertz \& Glaude (2001). My own work on Haitian is based on first-hand data collected with Herby Glaude, a Haitian native speaker and student in linguistics.

10. As opposed to derivational (lexical) morphology, $c f$. De Graff (2000)

11. As mentioned above [cf. (23)], la does not overtly combine with plural yo in all dialects. This may be analysed in purely phonological terms ( $c f$. Zribi-Hertz \& Glaude, 2001). In all Haitian dialects, the occurrence of the plural marker yo is only possible in spatialized noun phrases.

12. This conclusion is not inconsistent with the assumption that a substratic influence also played a part in the development of Haitian noun phrase structure. It is only inconsistent with a radically superstrate-discontinuous approach such as that proposed in Lefebvre (1998).

\section{REFERENCES}

Bernstein, J. (1997). Demonstratives and reinforcers in Romance and Germanic languages, Lingua 102, p. 87-113.

Chaudenson, R. (1992). Des îles, des hommes, des langues, Paris: L'Harmattan.

Christophersen, P. (1939). The articles. A study of their theory and use in English, Copenhagen: Munksgaard.

Corblin, F. (1987). Indéfini, défini et démonstratif, Geneva: Droz.

CRYstal, D. (1991). A dictionary of linguistics and phonetics, $3^{\text {rd }}$ printing, Oxford: Blackwell.

De GrafF, M., sld. (1999). Language creation and language change: creolization, diachrony, and development. Cambridge MA: MIT Press.

DÉprez, V. (2000). Parallel (as)symmetries and the internal structure of negative expressions, Natural Language \& Linguistic Theory 18: 253-342.

EMONDS, J. (1985). A unified theory of syntactic categories, Dordrecht: Foris.

Enç, M. (1991). The semantics of specificity, Linguistic Inquiry 22-1 : 1-26.

Frege, G. (1892). Über Sinn und Bedeutung, Zeitschrift für Philosophie und Philosophische Kritik 100: 22-50.

GAdÉLII, K. E. (1997). Lesser Antillean French Creole and Universal Grammar, Ph.D. dissertation, Département de linguistique, Université de Göteborg. 
Giusti, G. (1993). La Sintassi dei determinanti, Padova: Unipress.

Hawkins, J. (1978). Definiteness and indefiniteness: a study in reference and grammaticality prediction, London: Croom Helm.

HeIM, I. (1988). The Semantics of definite and indefinite noun phrases, New York: Garland.

Holmback, H. (1984). 'An interpretive solution to the definiteness effect problem', Linguistic Analysis 13: 195-215.

JESPERSEN, O. (1943). A Modern English grammar on historical principles, Part 7 : Syntax, Copenhagen: Munksgaard.

JosePH, F. (1988). La Détermination nominale en créole haïtien, unpublished dissertation, Université Paris-7.

KAYNE, R.S. (1994). The Antisymmetry of syntax, Cambridge MA: MIT Press.

Kempson, R. (1975). Presupposition and the delimitation of semantics, Cambridge: Cambridge University Press.

Kempson, R. (1988). Grammar and conversational principles. In Newmeyer F. (ed.) Linguistics: the Cambridge Survey, vol. II: Linguistic theory: extensions and implications, Cambridge: Cambridge University Press : 139-163.

KLeIBer, G. (1981). Problèmes de référence: descriptions définies et noms propres. Paris: Klincksieck.

KLEIBER, G. (1983). Les démonstratifs démontrent-ils ? Sur le sens référentiel des adjectifs et pronoms démonstratifs, Le français moderne 51-2: 99-117.

KLeIBer, G. (1984). Sur la sémantique des descriptions démonstratives. Lingvisticae Investigationes VIII-1: 63-85.

Kleiber, G. (1986). Pour une explication du paradoxe de la reprise immédiate. Langue française 72 : 54-79

KLEIBER, G. (1993). L'espace d'ICI: sur la pragma-sémantique des adverbes spatiaux. Le cas d'Il fait chaud ici. Cahiers de linguistique française 14: 85-104

LEFEBVRE, C. (1998). Creole genesis and the acquisition of grammar: the case of Haitian creole, Cambridge UK/New York: Cambridge University Press.

LONGOBARDI, G. (1994). Reference and proper names: a theory of N-movement in Syntax and Logical Form. Linguistic Inquiry 25-4 : 609-665.

LONGOBARDI, G. (2000). The structure of DPs: some principles, parameters and problems. In Baltin M. \& Collins C. (eds.), Handbook of contemporary syntactic theory, London: Blackwell

LYons, C. (2000). Definiteness, Cambridge UK/New York: Cambridge University Press.

MeILlet, A. \& J. Vendryès (1979). Traité de grammaire comparée des langues classiques, $5^{\text {th }}$ printing revised by J. Vendryès, Paris: Champion.

MiLsark, G. (1977). Existential sentences in English, New York: Garland.

Muller, C. (1996). La Subordination en français. Paris: Armand Colin.

Pompilus, P. (1976). Contribution à l'étude comparée du créole et du français - à partir du créole haïtien. Morphologie et syntaxe, Port-au-Prince: Éditions Caraïbes.

Postal, P. (1970). On so-called «pronouns» in English. In Jacobs R. \& Rosenbaum P. (eds.) Readings in English transformational grammar: 56-82, Waltham, Mass. : Ginn.

Russell, B. (1905). On denoting. Mind 14: 479-493.

SAusY, L. (1963). Grammaire latine complète, $7^{\text {th }}$ printing. Paris : Fernand Lanore.

SANDFELD, Kr. (1965). Syntaxe du français contemporain: la subordination. Geneva: Droz.

SCHACHTER, P. (1973). Focus and relativization. Language 49-1 : 19-46.

SYlvain, S. (1936). Le Créole haïtien, morphologie et syntaxe, Belgium: Wetteren. 
Vendler, Z. (1967). Singular terms. Linguistic and Philosophy. Ithaca NY: Cornell University Press.

Vergnaud, J.-R. (1974). French relative clauses, unpublished Ph.D. diss., MIT.

Vergnaud, J.-R. (1985). Dépendances et niveaux de représentation en syntaxe, Amsterdam/Philadelphia: John Benjamins.

ZRIBI-HertZ, A. \& H. Glaude (2001). Functional deficiencies in Haitian and French noun phrases: the syntax-morphology interface, unpublished ms., Université Paris-8.

\section{RÉSUMÉ}

Cet article examine le problème de la localisation de la 'définitude', c'est-àdire des traits responsables de l'identification du référent, au sein du groupe nominal. En se fondant sur des données comparatives du français et du haïtien, il met en question l'hypothèse courante stipulant que la définitude est un trait binaire ( \pm défini) généré dans la projection supérieure du syntagme nominal, 'DP'. Il est soutenu que les effets de 'définitude' peuvent être produits par au moins deux types de traits - le trait catégoriel [n], et des traits locatifs - qui peuvent occuper diverses positions structurales et peuvent aussi se combiner pour former une coquille fonctionnelle. Une dernière hypothèse, fondée sur les faits du haïtien, est que le Nombre peut être projeté au-dessus du ou des traits d'identification dans la structure syntaxique.

\section{MOTS-CLEFS}

Définitude, identification, structure du groupe nominal, hypothèse DP, français, haïtien, créolisation. 